\title{
Peran Guru Bimbingan dan Konseling terhadap Kreativitas Anak Berbakat
}

\author{
Desri Fitri Agung ${ }^{1}$, Alizamar ${ }^{2}$ \\ Universitas Negeri Padang ${ }^{12}$ \\ Correspondence Author, e-mail :desrifitriagung@gmail.com
}

\begin{abstract}
Bimbingan dan konseling adalah layanan yang di berikan kepada individu agar proses pendidikan siswa di sekolah tetap berjalan dengan baik dan lancar. Guru bimbingan dan konseling di sekolah memiliki kedudukan yang penting dalam proses belajar dan mengajar di karenakan guru bimbingan dan konseling tidak hanya mengentaskan siswa yang bermasalah akan tetapi yang tidak bermasalah juga. Kreativitas anak berbakat dilapang sangat banyak ditemukan namun tidak tersalurkan bagaimana semestinya. Faktanya di lapangan siswa yang memiliki kretivitas tinggi dan memiliki bakat yang hebat namun tidak tersalurkan sehingga bakat yang ada di dalam diri siswa terpendam dan tidak tersalurkan sebagaimana mestinya. Siswa yang memiliki kreativitas dan bakat yang tinggi ini sangatlah membutuhkan peran guru bimbingan dan konseling agar kebakatan yang dimilikinya tetap tersalurkan dan pendidikan siswa tetap berjalan dengan baik. Berdasarkan permasalahan di atas, penulis tertarik membahas "Peran Guru Bimbingan dan Konseling Terhadap Kreativtas Anak Berbakat
\end{abstract}

Keywords: Bimbingan dan Konseling, Kreativitas, Anak Berbakat

Article History: Received on 17/05/2019 Revised on 17/06/2019; Accepted on 15/07/2019; Published Online: $17 / 07 / 2019$. distribution, and reproduction in any medium, provided the original work is properly cited. $\odot 2019$ by author.

\section{PENDAHULUAN}

Pendidikan merupakan wadah tempat siswa-siswi untuk menuntut ilmu pengetahuan agar memperoleh ilmu. Dalam dunia pendidikan siswa memiliki ragam karakter serta memiliki kemampuan yang berbeda. Ada siswa yang memiliki kemampuan yang sedang dan ada siswa yang memiliki kemampuan belajar yang tinggi hal ini tentunya di pengaruhi tinggat intelegensi yang dimiliki siswa tersebut. Siswa yang memiliki tingkat belajar yang tinggi serta daya tanggapnya juga cepat termasuk kedalam anak berbakat.

Pendidikan di sekolah sangat di perlukan untuk pertumbuhan pola pikir serta pengetahuan siswa seputar dunia pendidikan. pendidikan sangatlah penting bagi setiap individu. Dalam proses belajar di sekolah siswamemiliki daya tanggap yang berbedabeda antara satu dan yang lainya dan juga daya tanggap siswa dalam belajar di pengaruhi oleh tingkat intelegensi yang dimiliki oleh siswa itu sendiri. Setiap indidvidu memiliki intelegensi yang berbeda yang mana ntuk menentukan intelegensi siswa tentunya menggunakan alat ukuryang dilakukan oleh tenaga profesiona. Ana berbakat 
memiliki intelegensi 110 ke atas.Anak berbakat di dunia pendidikan seharusnya perlu di perhatikan agar tersalurkan kebakatannya dan diberikan fasilitas yang sesuai dengan kebakatan yang dimilikinya. Di dalam dunia pendidikan guru bimbingan dan konseling merupakan guru yang perlu memperhatikan anak berbakat agar kebakatan yang dimiliki anak tersalurkan sebagaimana mestinya.

Upaya bantuan yang diberikan kepada siswa untuk menemukan jati diri secara pribadi baik secara internal maupun eksternal, mengenal lingkungan sekitar serta merencanakan masa depan melalui bakat yang dimilikinya, bimbingan yang diberikan kepada siswa dalam rangka merencanakan masa depan serta mempersipaka diri untuk menata masa depan yang cerah (Amti, 2004: 30-31).

Anak berbakat merupakan bibit unggul yang sangat perlu untuk di kembangkan kebakatan yang dimilikinya agar bakat yang di milikinya dapat tersalurkan dan berkembang dan tentunya dibimbing oleh tenaga professional yang mengerti mengenai kebakatan yang dimiliki oleh siswa tersebut.

Menurut (Munandar, 2014: 1) tanda-tanda individu yang memiliki keberbakatan ada 3 hal yaitu tingkat kecerdasan yang dimiliknya di atas rata-rata, memiliki kreativitas serta memiliki motivasi secara internal yang tinggi.

Siswa yang memiliki kreativitas yang tinggi biasanya mampu melahirkan hal-hal baru sehingga dapat mengasah pola pikir. Siswa yang kreatif dan inovasi otaknya selalu bekerja dan tidak bisa diam karena dalam dirinya selalu ingin bekerja dan bekerja. Kreativitas anak berbakat disekolah hendaknya perlu diperhatikan dan hal tersebut juga dapat dijadikan referensi oleh guru bimbingan dan konseling di sekolah dalam mengidentifikasi serta mengembangkan kretaivitas yang ada pada anak berbakat.

Banyak hal yang dapat dilakukan dalam mengidentifikasi anak berbakat selain dengan kreativitas juga dapat dilihat segi belajar atau hasil belajarsiswa di kelas dan kemampuan siswa di luar kelas.contohnya saja estrakulikuler yang di ikuti siswa juga merupakan salah satu referensi yang dapat digunakan oleh guru bimbingan dan konseling dalam mengidentifikasi anak bebakat.

Kreativitas merupakan hasil dari interaksi antara individu dengan lingkungan sekitanya yang mana kreativitas juga dapat di tingkatkan melalui pendidikan (Munandar, 2014: 12-13)

Menurut (Amin, 2019) untuk pengembangan kreativitas siswa, kita perlu meninjau empat aspek dari kreativitas, yaitu pribadi, pendorong, press, proses, proses, atau, dan produk (4P dari kreativitas).

Oleh sebab itu agar kebakatan yang dimiliki siswa tetap tersalurkan dan kreativitas siswa tetap berkembang di dalam dunia pendidikan guru bimbingan dan konseling memiliki peran yang sangat penting dalam hal ini 


\section{PEMBAHASAN}

Bimbingan dan konseling terdiri dari dua kata yaitu bimbingan serta konseling. Bimbingan adalah memberi bimbingan kepada peserta didik untuk menemukan dirinya pribadi dan dapat menemukan kelemahan dan kelebihan nya secara sendiri, sedangkan konseling adalah pertemuan secara empat nama dalam pengentaskan hal-hal yang dirasakan dan menganggu kegiatan keseharian klien sesuai dengan kaidah serta normanorma yang berlaku (Sukardi, 2010: 36-38).

Pada hakikatnya bimbingan adalah proses bantuan yang dberikan kepada individu yang dirasakan memerlukan bantuan agar KES-T menjadi KES, contohnya saja di lapangan di dalam kelas siswa malas belajar dan suka tiduran saja akan tetapi siswa memiliki intelegensi yang tinggi, anak ini memerlukan guru bimbingan dan konseling agar permasalahan yag dirasakannya bisa di entaskan. Guru bimbingan dan konseling tidak hanya mengentasan siswa yang bermasalah sja akan tetapi siswa yang tidak bermasalah juga contohnya siswa yangmemiliki potensi di bidang biologi akan tetapi tidak pernah mengikuti olimpoade dan hanya banyak diam di kelas akan tetapi saat belajar nilainya tinggi dan dapat dilihat dari hal ini siswa yang seperti ini memiliki bakat dibiang biologi namun dirinya tidak mampu mengembangkat bakat dalam dirinya da daam halini lah guru bimbinan dan konseling memainkan perannya sebagai guru bimbingan dan konseling profesional agar siswa menemukan tempat yang tetap serta yang cocok untuk dirinya dalam mengembangkan kebakatan yang dimilikinya.

Menurut (Prayitno \& Erman, 2004) tujuan dari bimbingan dan konseling adalah untuk membantu klien dalam menentukan pilihan hidup.untuk menentukan arah tujuan hidup yanglebih baik terlebih klien yang memiliki kebakatan yang

Siswa yang memiliki intelegensi 110 ke atas sudah di nyatakan anak berbakat yang mana setiap individu memiliki bakatnya masing-masing namun ada yang menonjol dan ada yang tidak. Karakterstik anak berbakat yaitu memiliki sensitivitas yang tinggi, idealis, memiliki rasa keadial yang tinggi (Wahab, 2010). 
Agung, D., \& Alizamar, A. (2019) 59

Berbakat ialah mereka yang diidentifikasi oleh orang-orang profesional memiliki kemampuan yang sangat menonjol, sehingga memberikan prestasi yang tinggi (Munandar, 1982).

Menurut (Renzulli, 1978) dari teorinya sediri meyebutkan "three dimensional model" atau "three-ring conception" tentang keberbakatan. Keberbakatan mencakup tiga dimensi yang saling berkaitan, yaitu (a) kecakapan di atas rata-rata, (b) kreativitas, dan (c) komitmen pada tugas.

Menurut (Munandar, 2014: 24-25) konsep Renzulli mengenai keberbakatan ada tiga hal yaitu:

1. Kemampuan di atas rata-rata, terkadang kesalahan guru dalam mengidentifikasi anak berbakat dari nilai yang rendah sehingga siswa yag memiliki nilai jelek di dalam kelas bukan anak berbakat. Siswa yang berbakat bukan dari segi nilai di dalam kelas saja namun anak berbakat juga memiliki bakat di luar kelas misalnya di bidang music dan olahraga.

2. Kreativitas, anak berbakat memiliki kemampuat untuk mengemukankan gagasan dan ide-ide baru yang kreatif dan inovasi.

3. Pengikat diri terhadap tugas, anak berbakat tekun dalam mengerjakan tugas-tugas dan juga mampu melawan rasa malas dalam dirinya.

Menurut (Munandar, 2009) ada tiga faktor yang menyebabkan anak berbakat memilki masalah atau kesulitan dan ketegangan yaitu: kepribadian misalnya perfeksionis, kondisi lingkungan dan semangat yang berlebihan sehingga membuat stress.

Menurut Suprihatin (2015: 73-82) ada beberapa karakteristik anak berbakat akademik di antaranya sebagai berikut:

a. Memiliki IQ yang sangat tinggi

b. Memiliki kebiasaan kerja yang jelek atau tidak berniat melakukanny

c. Ketidakmampuan berkonsentrasi atau susah fokus

d. Kurang usaha dalam menjalankan tugas

e. Minat yang kuat terhadap suatu bidang tertentu, sehingga melupakan akademiknya

f. Pekerjaaannya sering tidak selesai atau sering menunda-nunda

g. Harga dirinya rendah

h. Menampilkan frustasi emosional

i. Bersikap negatif terhadap diri sendiri dan orang lain. 
Dalam hal ini bimbingan dan konseling memiliki tiga bidang fungsi mengenai anak berbakat yaitu konseling, konsultasi dan koordinasi. Anak berbakat merupakan siswa yang memiliki potensi dan kemampuan yang melebihi dari teman-teman nya yang lain serta kemampuan yang dimilikinya juga tidak banyak dimiliki oleh orang lain.

\section{KESIMPULAN}

Anak berbakat adalah mereka orang-orang yang di identifikasi oleh orang-orang profesional yang memiliki kemampuan tertentu dan tidak banyak dimiliki oleh orang lain. Anak berbakat memiliki intelegensi 110 ke atas dan juga anak berbakan memiliki beberapa bidang kemampuan dan salah satu bidang tersebut ada dalam dirinya. Di dalam dunia pendidikan populasi anak berbakat sangat perlu untuk diperhatikan agar kebakatan yang dimiliki siswa tetap berkembang dan bisa meningkatkan kemampuan yang dimilikinya. Selain hal tersebut peran guru bimbingan dan konseling sangatlah penting karena guru bimbingan dan konseling harus memperhatikan anak bebakat dan membantu siswa dalam menentukan arah karir sesuai dengan bakat yang dimilikinya.

\section{REFERENCES}

Amin, M. (2019). Pengaruh Pendekatan Pembelajaran Saintifik Terhadap Kreativitas Belajar Siswa di. Jurnal Dirasah, 2(1), 1-8. https://doi.org/p-ISSN: 2615-0212, e-ISSN; 2621-2838

Munandar, U. (1982). Pemanduan Anak Berbakat. Jakarta: Rajawali Pers.

Munandar, U. (2009). Model Layanan Pendidikan Anak Berbakat san Alternatif Penerapanya di Indonesia. Seminar Internasional. Surakarta: UNS.

Munandar, U. (2014). Pegembangan Kreativitas Anak Berbakat. Jakarta: Rineka Cipta.

Prayitno \& Erman, A. (2004). Dasar-dasar Bimbngandan Konseling. Jakarta: Rineka Cipta.

Renzulli. (1978). What Make Giftedness. Re-examining a Definition: Universty of Connecticut.

Sukardi, D. K. (2010). Pengantar Pelaksanaan Program Bimbingan dan Konseling di Sekolah. Jakarta: Rineka Cipta.

Suprihatin, S. (2015). Upaya guru dalam meningkatkan motivasi belajar siswa. Jurnal Pendidikan Ekonomi UM Metro, 3(1), 73-82.

Wahab, R. (2010). Konselng Bagi Anak Berbakat Akademik. Cakrawala Pendidikan, (1). 